\title{
A SWOT Analysis of Chinese Construction Firms at the International Market
}

\author{
Shigang YAN \\ China Foreign Affairs University \\ Beijing, P.R.China \\ e-mail: yanshigang@cfau.edu.cn
}

\begin{abstract}
As an important participant in the international construction market, Chinese construction firms (CCFs) are confronted with the tasks of keeping themselves competitive. The paper put forward the development stages and current situations of $\mathrm{CCF}$ at the international market. To help construction firms maintain and improve their competitiveness, this research utilizes the SWOT method to analyze the international competitiveness of Chinese contractors.
\end{abstract}

Keywords-construction firms; China, SWOT; international competitiveness

\section{INTRODUCTION}

Construction has been one of the most important economic activities during the process of humankind's remaking of natural environments. Construction is driven and affected by the international economy, and it has a worldwide impact. With the rapid development of the Chinese economy and China's internationalization, Chinese construction firms (CCFs) have been given great opportunities in venturing abroad and acquiring wideranging experience, enhancing their knowledge and skills. Some CCFs have made significant achievements in the international construction market. The number of CCFs that have emerged in the Engineering News Record (ENR) Top 250 International Contractors list has increased from a mere 4 in 1992 to 65 in 2015.

The rapid emergence of CCFs in international markets has generated much interest in their competitors around the globe as well as in researchers (Chen \&Orr, 2014; Co, 2014). Despite the sharp increase in the number of CCFs in recent years, the average revenue generated by each firm is far less than their counterparts from the advanced countries (Zhao and Shen, 2008; Yan and Liu, 2017). As latecomers to the international market, the appropriate strategic selection of international construction market thus becomes important for CCFs. However, based on extensive literature review, it was found that there are few empirical studies on how to improve CCFs' international competitiveness. This paper provides the SWOT method to analyze the international competitiveness of Chinese contractors.

\section{Stages OF CCFs AT THE INTERNATIONAL MARKET}

Before 1980s, only a few CCFs were involved in international projects under the Chinese government's foreign aid to the third world countries (Low and Jiang 2003). However, after China adopted the open-door economic policy in 1979, CCFs' international business has witnessed a progressive development. In retrospect, such a development can be classified in three distinct stages, briefly as follows:

\section{A. Preliminary Stage (1979-1982)}

Four large CCFs were the first to be approved by the Chinese government to undertake international construction in 1979. They started their work in the Middle East. By the end of 1982, the government had approved 29 firms for international construction. By then, 755 contracts had been secured, with a total value of US\$1.25 billion (Low and Jiang, 2003). Projects completed were worth US\$560 million, covering markets in 45 countries and regions. Major markets were West Asia and North Africa, with major projects in building and road construction. Most of the projects were sub-contracts and small in scale.

\section{B. Stable Development Stage (1983-1989)}

This stage coincided with the recession of the world economy, during which construction demands in the Middle East and North Africa suddenly declined. CCFs had to expand into other regional markets. By 1989, 88 CCFs had obtained international business licenses. During this period, the total transacted value of international construction and labor services was US\$7.22 billion. Business has been expanded to more than 130 countries, with Asia as the biggest market, accounting for 60 percent of the business. Besides buildings, road and bridge projects, a number of power stations and industrial plants were built.

\section{Fast Development Stage (1990-present)}

In 1990, CCFs had to give up the Middle East market after the Gulf War. With government support, CCFs were involved in many construction projects in Russia, Eastern Europe, Asia, Africa and Latin America. During this period, SOEs have been progressively restructured and become more adaptable to the international market. From 1997, many large SOEs were severed from respective government ministries, and put under the supervision of a new committee. As a result, CCFs grew at an annual rate of 20 percent internationally. More than 2000 contractors had been licensed for international business. CCFs have since played an increasingly significant role in international construction. Currently they are re-entering the Middle East market and expanding their business in AICs as well. 


\section{DEVELOPMENT OF CCFS AT THE INTERNATIONAL CONSTRUCTION MARKET}

\section{A. Current Situation of International Construction Market}

Engineering News Records (ENR) defined the international construction market as the specified volume open to foreign construction firms in the international market. The International construction 2020 report forecasted that construction in emerging markets would double in size over the next decade, growing by an estimated $110 \%$ to become a market worth $\$ 7$ trillion, representing a massive $17.2 \%$ of international GDP in 2020 (Parsa et al., 2015).

The increasing international construction market could be supported by the ENR's annual statistics, which has shown that Top 250 International contractors have increased their revenue in the international markets over the last decade (ENR, 2016). In comparing the top 250 international contractors over the past decade, the revenue generated by these firms has increased from US $\$ 224.4$ billion in 2006 to US $\$ 544.0$ billion in 2015(ENR, 2016); therefore it can be stated that large international contractors are finding an abundance of work in the international market.

The Asian market has rebounded with fast growth after several years of financial crisis. Total construction revenue in Asia and Austria for Top 250 International contractors reached US\$ 120.8 billion, accounting for $24.2 \%$ of their international revenues. The revenue for Top 250 International contractors at Europe reached US $\$ 93.4$ billion, accounting for $18.7 \%$ of their international revenues. The revenue for Top 250 International contractors at Middle East and USA reached US\$ 76.5 billion and US\$ 53.4 billion respectively, accounting for $15.3 \%$ and $10.7 \%$ of their international revenues (ENR, 2016).

\section{B. The Market Share of CCFs at the International Construction Market}

In 2015, the gross contracting revenue of the 65 Chinese contractors reached US\$ 93.7 billion and accounted for $19.3 \%$ of the top 250 contractor's revenue (ENR, 2016). The Africa market contributed to US\$ 35.4 billion and accounted for $54.9 \%$ of their international revenues for the top 65 Chinese contractors. The revenue for Top 65 Chinese contractors at Asia reached US\$ 30.2 billion, accounting for $25.0 \%$ of their international revenues. The revenue for Top 65 Chinese contractors at Middle East and Latin America reached US\$ 13.1 billion and US\$ 7.5 billion respectively, accounting for $17.2 \%$ and $13.7 \%$ of their international revenues.

Chinese contractors' share of the international market is still smaller in comparison with their competitors. The international revenue generated by the top 52 European construction firms accounted for $43.6 \%$ of all total international revenue received in 2015. The main markets of operation for European contractors can be observed as the United States, Europe and Latin America. In comparison, the top 65 Chinese contractors achieved $19.3 \%$ of total international revenue. This comparison indicates that Chinese contractors should enhance their international competitiveness to achieve wider markets, when compared to their Western counterparts.

\section{Types of Works Undertaken by CCFs}

The types of international construction projects undertaken by CCFs can be categorized as follows: general building, transportation, power, petrochemical, manufacturing, sewage treatment, water supply, telecommunication projects, etc. (Zhao and Shen, 2008).

In 2015, the top three types of works involving CCFs are general building, transportation and petrochemical projects. There is a trend from 2011 to 2015 towards more diversification in CCFs' construction business. General building works remain the biggest share. More projects involving high technology and financial requirements have been undertaken, including large industrial manufacturing, power, water supply and telecommunication works.

\section{SWOT ANALYSIS OF CCFS AT THE INTERNATIONAL MARKET}

SWOT analysis facilitates to identify the current issues of Chinese contractors in the international construction market, which will provide a systematic review of CCFs' international competitiveness. To understand the external factors that influence CCFs' development and internationalization, the broad opportunities and potential threats for CCFs will be analyzed. Concurrently, CCFs' internal strengths and weaknesses will be examined, in relation to their international competitors, in the following SWOT analysis.

\section{A. Opportunities of CCFs at the international market}

The opportunities for CCFs can be attributed to two broad aspects - the favorable domestic environment and the opportunities arising from the international environment.

1) Favorable domestic environment

The favorable domestic environment is underpinned by four developments. First, the stable political situation and economic environment at home provide a solid basis for CCFs' business growth. Currently China has a stable political climate under a strong central government leadership. The booming economy has been underpinned by huge investments in fixed assets/infrastructure. The construction industry and CCFs are set to benefit from such an environment. Second, there is positive impact on the construction industry and CCFs arising from China's WTO entry in 2001. Market entry barriers will be lowered in member countries after China's accession to the WTO, which will strengthen CCFs' chances of securing construction projects in these countries.

Third, more technically complex mega projects are emerging in China. Construction contracting modes are becoming more sophisticated, following increasing internationalization and privatization of the domestic market. Participation in such world-class projects will improve CCF's construction capability. BOT, PPP, EPC and other complicated contracting modes are set to be widely used in China, which will enhance CCF's financing and project 
management capability. As a result, CCFs' overall competitiveness will be strengthened.

Fourth, the increase in foreign investment projects and the resultant rivalry between $\mathrm{CCF}$ s and foreign contractors in China will enhance CCF's international competitiveness. Foreign contractors entering China often need to cooperate with CCFs to increase their chances of securing projects. Such cooperation allows CCFs to enhance their management and technological competencies. Such collaborative experiences also enable both parties to venture into any third countries.

2) Opportunities from the international environment

The international environment has given rise to three opportunities for CCFs. First, the international economy has recovered from its downturn and the current stable growth has boosted the demand of construction in many countries. The resultant increase in infrastructure spending provides more opportunities for international contractors including CCFs. In addition, some "chance" events, such as wars and natural disasters, which are prevalent nowadays, also provide rebuilding opportunities in the affected markets.

Second, as more CCFs become top international contractors, their image and reputation have undergone drastic improvement in international arena. They have been focusing on building their brand name and embracing higher quality and technology construction. This will enable them to compete with their international rivals from AICs. Clients would have no reason to reject CCFs if they could implement projects at low costs yet deliver similar or better quality than others.

Third, overseas investment of Chinese enterprises has increased dramatically, providing abundant opportunities for CCFs to construct the overseas facilities of these Chinese investors. Besides, the increase in government-led international investment in energy sourcing will also provide more opportunities for CCFs in the construction of such projects.

\section{B. Threats of CCFs at the international market}

The potential threats to CCFs can be attributed to four aspects. First, China's WTO entry will lead to a more intense competition between CCFs and their rivals from AICs in the Chinese construction market. A number of top international contractors and design firms from AICs are now involved in the design and construction of sophisticated mega projects in China. CCFs would have no alternatives but to become their partners or subcontractors. Furthermore, Sino-foreign JVs between foreign contractors and privately-owned CCFs will pose greater threats to state-owned CCFs, as these JVs combine foreign partners' financing and technology advantage with flexible management of non-state-owned Chinese partners.

Second, market entry barriers of some AICs still persist despite being lowered after China's WTO entry, as discussed earlier. Such entry barriers deter CCFs from the geographical expansion into these markets.

Third, even in NICs and LDCs, the trend of international construction is towards greater emphasis on financing, technology and sophisticated project management.
International contractors from AICs are naturally favored over CCFs as the former possess such advantages.

Fourth, while painstakingly competing with their international rivals, CCFs are also competing among themselves in foreign markets with increasing internationalization. CCFs have yet to establish a cluster approach to compete internationally. The coordination from Chinese government agencies is found to be lacking. The outcome is that CCFs' international rivals will benefit from their internal competition.

\section{Internal strengths of CCFs at the international market}

Compared to their international competitors, CCFs' strengths mainly lie in four aspects: cost advantage, strong home market support, specialization in certain types of construction works, and good relationship building (Yan and Liu, 2017).

First, CCFs have obvious cost advantage in most international markets. Abundant natural and manpower resources have led to lower costs of labor, construction materials and equipment. CCFs have also increased the employment of indigenous workforce in many LDCs markets. Coupled with the deployment of Chinese engineers overseas, CCFs' costs are far lower than most international competitors.

Second, the strong home market can provide CCFs with sufficient projects which are usually more profitable than their international projects. The international construction is carried out to expand CCFs' overseas market share, and alleviate a labor-surplus situation at home. Hence, compared to other international contractors which are forced to go abroad due to poor home market conditions, such as Turkish and Singaporean contractors, CCFs can afford to be more aggressive internationally as the home market provides a buffer to any overseas risks.

Third, a few large CCFs have become top international contractors for certain types of work and in some particular markets, as ranked by ENR. A number of CCFs have developed their own technologies, machinery and equipment, and special materials or products, which are accepted by the clients in most NICs and LDCs.

Fourth, Chinese cultural values of trust and relationship enable CCFs to create a favorable environment for conducting business that can lower cost, shorten duration, and improve performance. CCFs are adept in generating goodwill among all project stakeholders which put them in a competitive position when compared to the legalistic and transactional approach adopted by most contractors from AICs.

\section{Internal weaknesses of CCFs at the international market}

\section{1) Lack of international exposure}

On average, international construction revenues of CCFs only account for a small proportion of their total revenues, compared with their counterparts from AICs. Besides, China is lacking of large-sized contractors with high internationalization extent. For example, the international revenue of ACS in 2015 accounted for 83.1 percent of its 
total revenue, which was 1.66 times of the combined international revenue of China Communication Construction Group (ENR 2016). In contrast, the international revenue of China Communication Construction Group only accounted for 28.2 percent of its total. In addition, CCFs are still focusing on general contracting construction projects. Their international projects are usually small in size and less sophisticated compared to large AICs contractors, although they have undertaken a number of large projects in Asia and Africa.

\section{2) Weaknesses in financial capability}

The lack of financing capability and shortage of capital are the major obstacles for CCFs to secure large international projects (Yan and Liu, 2017). With the increasing trend of project finance for both domestic and international clients, CCFs will need to expand their financing channels. However, their financing capability still lags far behind their international competitors. Unlike CCFs, these competitors have built up close relationship with financial institutions and banks and many have also enhanced their financial strength through public offerings.

\section{3) Weaknesses in technology and innovation}

In terms of technical expertise, CCFs have few advantages when compared with their competitors from AICs, especially in R\&D. Most large international contractors from AICs emphasize R\&D, and try to apply the most advanced technical know-how. CCFs have recognized this weakness and have started to invest in R\&D. An example is CSCEC's setting up of a technical center, the biggest construction R\&D center in China. Besides lacking in $\mathrm{R} \& \mathrm{D}, \mathrm{CCF}$ are also slow to adopt state-of-the-art technology in construction.

4) Lack of experienced managerial staff

Low productivity and profitability reflect the weakness of CCFs in their management. This weakness could be attributed to the lack of experienced mid-level professionals and expatriate managers and the inexperience of top managers. Top managers of state-owned CCFs are usually appointed by the government. As political appointees, most of them have no international experience and lack management competence. They consider internationalization as a political task under the "Going Abroad" strategy. Their decisions on international business were often made without sufficient feasibility study and due diligence, resulting in frequent financial losses.

\section{5) Inappropriate organizational structure}

Most of the large CCFs are apparently less competitive due to their over-centralized and informalized structure, overstaffing and heavy social responsibility burden. Many CCFs are unable to handle the complexity arising from autonomy and centralization. Loss of control in the midst of autonomy and failures caused by centralization are common problems that continue to plague CCFs' corporate leaders. In contrast, international contractors from AICs have effective, streamlined organizational structure with a lean and competitive workforce.

\section{ACKNOWLEDGMENT}

The research is supported by Fundamental Research Funds for the Central Universities (No. 3162014ZYKC03).

\section{REFERENCES}

[1] C. Chen, and R.J.Orr, "Chinese contractors in africa: home government support, coordination mechanisms and market entry strategies," Journal of Construction Engineering and Management, Vol.135, No.11,pp. 1201-1210, 2014.

[2] C.Y. Co, "Chinese contractors in developing countries," Review of World Economics, Vol.150, No.1, pp.149-171,2014.

[3] Engineering News Record (ENR)(2016). The top 225 international contractors. [Online] Available: http://www.enr.com/toplists 12015_Top_250_International_Contractors (July 10, 2016).

[4] S.P. Low, and H.B. Jiang, "Internationalisation of Chinese Construction Enterprises", Journal of Construction Engineering and Management, American Society of Civil Engineers, Vol. 129, No. 6, pp. 589-598, 2003.

[5] A.Parsa, S.Huston, A.Kashyap, and P. Li, "The international competitiveness of Chinese construction firms", European Real Estate Society (ERES) Conference, 24-27th June, 2015, Istanbul, Turkey.

[6] R. T.Wilson, and D. W.Baack, Attracting foreign direct investment: Applying Dunning's location advantages framework to FDI advertising. Journal of International Marketing, Vol.20, No. 2, pp.96$115,2012$.

[7] S.G. Yan and G.Z. Liu, "Competitive strategy, market entry mode and international performance: Business and Management Studies, vol. 3, No.1, pp. 1-9, 2017.

[8] Z. Y.Zhao, and L. Y. Shen, "Are Chinese contractors competitive in international market?" Construction Management and Economics, Vol.26, No.26, pp.225-236, 2008. 